\title{
PENINGKATAN PEMAHAMAN MASYARAKAT DESA BATANG KULIM KECAMATAN PANGKALAN KURAS KABUPATEN PELALAWAN MENGENAI UNDANG-UNDANG NOMOR 16 TAHUN 2011 TENTANG BANTUAN HUKUM
}

\author{
Yetti $^{* 1}$, Robert Libra ${ }^{2}$ \\ 1,2Fakultas Hukum, Universitas Lancang Kuning \\ *E-mail: robertlibra87@gmail.com
}

\begin{abstract}
The need for understanding the existence of a Legal Aid program for the poor from the government is very Urgent. The Chairperson of the BPD in Batang Kulim Village requested the service team, so that the community was given legal counseling. There are so many people who do not know about the existence of legal aid programs, if litigation for people who are not able to get services is free, not only that the court fees will also be borne by the State. The Community Service activity was held on Monday, February 22, 2018 at Pak Yanto's House. One of the Resident Houses in Batang Kulim Village, Pelalawan Regency, Riau, during the community weekly wird, was there, Chairman of the RT, Chairman of the BPD and the Batang Kulim Village Equipment. This activity starts at 8:00 p.m. WIB until 10:00 p.m. WIB. The number of participants present were 30 people. The output that will be produced according to the plan for community service activities is: for partners, of course, an increase in understanding of Law Number 16 Year 2011 concerning Legal assistance. For the outcome proposals to be achieved are in the form of scientific articles and cannot be separated from the Tri Darma of Higher Education.
\end{abstract}

Keywords - Increased Understanding, Legal Aid

\begin{abstract}
Abstrak
Kebutuhan tentang pemahaman mengenai adanya program Bantuan Hukum untuk masyarakat miskin dari pemerintah sangatlah Urgent. Ketua BPD Desa Batang Kulim meminta pada tim pengabdian, supaya masyarakatnya diberikan penyuluhan hukum. Banyak sekali masyarakat yang tidak mengetahui tentabng adanya program bantuan hukum, apabila berperkara bagi masyarakat yang tidak mampu akan mendapatkan pelayanan Cuma-Cuma, bukan hanya itu biaya perkara juga akan ditanggung oleh Negara. Kegiatan Pengabdian kepada masyarakat ini telah dilaksanakan pada hari Senin tanggal 22 Februari 2018 bertempat di Rumah Pak Yanto Salah seorang Rumah Penduduk di Desa batang Kulim Kabupaten Pelalawan Riau pada saat wirid Mingguan masyarakat, hadir disana Ketua RT, Ketua BPD dan Perangkat Desa Batang Kulim. Kegiatan ini dimulai Pukul 20.00 WIB sampai dengan 22.00 WIB. Jumlah peserta yang hadir adalah sebanyak 30 orang. Luaran yang akan dihasilkan sesuai rencana kegiatan pengabdian kepada masyarakat ini adalah: bagi mitra tentunya peningkatan pemahaman terhadap Undang-undang Nomor 16 Tahun 2011 tentang bantuan Hukum. Bagi pengusul luaran yang akan dicapai adalah berupa artikel ilmiah dan tidak terlepas juga dari Tri Darma Perguruan Tinggi.
\end{abstract}

Kata kunci-Peningkatan Pemahaman, Bantuan Hukum

\section{PENDAHULUAN}

\section{Analisis Situasi}

Desa Batang Kulim Kabupaten Pelalawan Provinsi Riau merupakan salah satu Desa di Kabupaten Pelalawan. Kebutuhan tentang pemahaman mengenai adanya program Bantuan Hukum untuk masyarakat miskin dari pemerintah sangatlah Urgent. Ketua BPD Desa Batang Kulim meminta pada tim pengabdian, supaya masyarakatnya diberikan penyuluhan hukum. Banyak sekali masyarakat yang tidak mengetahui tentabng adanya program bantuan hukum, apabila berperkara 
bagi masyarakat yang tidak mampu akan mendapatkan pelayanan Cuma-Cuma, bukan hanya itu biaya perkara juga akan ditanggung oleh Negara.

Bantuan hukum seharusnya memperhatikan faktor-faktor yang menyebabkan ketidakadilan bagi masyarakat miskin dan faktor-faktor penghambat ketika masyarakat miskin berusaha mengakses bantuan hukum tersebut. Pengalaman masyarakat miskin ketika mengakses bantuan hukum itulah yang kemudian dituangkan dalam berbagai peraturan perundang-undangan mengenai bantuan hukum sehingga bantuan hukum tidak semata-mata diartikan sebagai jasa dari pengacara kepada masyarakat miskin melainkan merefleksikan realitas yang dihadapi.

Konstitusi menjamin hak setiap warga neraga mendapat perlakuan yang sama di muka hukum, termasuk hak untuk mengakses keadilan melalui pemberian bantuan hukum. Orang kaya dan mempunyai kekuasaan, dengan mudah mengakses dan mendapatkan keadilan, melalui tangantangan advokat yang disewanya. Tidak demikian halnya kelompok masyarakat miskin, mereka tidak mampunyai kemampuan untuk memahami hukum dan tidak mampu untuk membayar advokat, hal demikian menyebabkan tidak ada perlakuan yang sama dimuka hukum untuk mengakses keadilan. Problem dasar yang muncul adalah tidak adanya perluasaan akses yang sama bagi setiap warganegara untuk mendapatkan perlakuan yang sama dimuka hukum, meskipun doktrinnya keadilan harus dapat diakses oleh semua warga negara tanpa terkecuali justice for all/accessible to all. (Pujiono, 2010)

Kemiskinan telah membawa bencana bagi kemanusiaan, tidak hanya secara ekonomis tetapi juga secara hukum dan politik. Seorang kaya yang biasanya akrab dengan kekuasaan dapat menerjemahkan keadilan dengan kekuasaan yang dimilikinya. Hal ini kemudian menyebabkan ketidakadilan. Bagi masyarakat miskin kebutuhan mendapatkan keadilan tidak dengan mudah mereka dapatkan karena kemiskinannya karena itulah mereka membutuhkan bantuan hukum untuk mendapatkan hak mereka tersebut. Namun, sayangnya masyarakat miskin tidak begitu saja mendapatkan bantuan dari masalah hukum yang dihadapinya, berbeda dengan masyarakat kaya yang dengan kekayaannya dapat membuat hukum dekat dengannya.

Masyarakat miskin yang menghadapi masalah hukum harus menghadapi kenyataan bahwa kondisi sosial politik mereka telah menjadikan mereka tidak dapat mengakses bantuan hukum yang mereka butuhkan. Kemiskinan yang berakibat terhadap rendahnya taraf pendidikan dan pengetahuan menjadikan masyarakat tidak sadar akan hak-haknya. Namun, walaupun mereka sadar akan hak-hak ini tidak serta merta menjadikan mereka dapat mendapatkan keadilan yang mereka cari. Sistem hukum disediakan negara bagi mereka dianggap mahal, tidak mudah diakses dan jauh dari tempat tinggal mereka. Ditambah lagi, saat ini hukum dianggap telah dikomersialisasi, sehingga masyarakat miskin tidak akan lagi mampu mendapatkan keadilan. Adanya mafia hukum di hampir setiap level instansi hukum ditambah lagi gambaran mengenai advokat yang dianggap mahal dengan tarif yang tidak akan mampu dibayar oleh masyarakat miskin yang penghasilannya hanya cukup untuk makan sehari-hari.

Masalah hukum bagi masyarakat miskin dan marginal bukan semata-mata masalah mereka paham aturan hukum atau tidak, tetapi di negara-negara yang mana masyarakat menderita kemiskinan secara struktural, masalah hukum menyangkut posisi tawar mereka yang rendah jika dihadapkan dengan negara atau para pemilik modal. Masyarakat miskin karena memang dibuat miskin, bukan dilahirkan miskin. Kesempatan untuk menjadi seimbang tidak pernah ada sehingga bantuan hukum yang diberikan kepada mereka harus juga melihat kepada posisi mereka ini. Pada awal tahun 1970-an, Lembaga Bantuan Hukum Indonesia mengusung Bantuan Hukum Struktural (BHS) yang ditujukan selain untuk memberikan pendampingan hukum bagi masyarakat miskin yang berkasus juga meningkatkan posisi tawar mereka melalui penyadaran hak-hak mereka dan mendorong perbaikan hukum untuk mengisi kebutuhan masyarakat yang terus berkembang. (Adnan buyung nasution, 2010)

Berkaitan dengan status mereka yang miskin, sistem bantuan hukum yang dibangun oleh negara juga tidak berpihak kepada masyarakat miskin yang harusnya menjadi sasaran bantuan hukum. Negara dinilai pasif dalam hal pemberian bantuan hukum bagi kelompok masyarakat miskin ini. Bantuan hukum dikonstruksikan dalam berbagai perundang-undangan hanya berfungsi jika masyarakat berhadapan dengan hukum di pengadilan, bahkan dalam kasus pidana hanya yang diancam hukuman lima tahun atau lebih yang bisa mendapatkan bantuan hukum yang mereka butuhkan tanpa diminta. Negara tidak melihat bahwa dari hari ke hari masyarakat miskin 
menghadapi pelanggaran-pelanggaran hak-hak mereka dan mereka tidak bisa mendapatkan bantuan hukum karena negara tidak memasukkan jenis pelanggaran hak ini sebagai kasus yang bisa mendapatkan bantuan hukum.

Pasifnya negara dalam memberi bantuan hukum kepada masyarakat miskin dapat dilihat dari kasus yang menggemparkan masyarakat pada tahun 2009 lalu kasus pencurian kakao oleh Nenek Minah". Nenek Minah seorang perempuan tua yang dituduh mencuri tiga kakao perusahaan perkebunan, mengikuti proses pengadilan tanpa didampingi oleh seorang pengacara dan dia terpaksa mengeluarkan uang sendiri untuk biaya transport dari rumahnya ke pengadilan yang melebihi penghasilannya sehari-hari. Nenek Minah mengaku kepada wartawan bahwa dia tidak didampingi pengacara karena tidak tahu apa pengacara itu. Terlebih lagi, sebagai masyarakat desa yang buta huruf nenek ini tidak paham dengan pasal pasal 21 dan pasal 47 Undang-Undang Nomor 18 tahun 2004 tentang perkebunan yang dituduhkan kepadanya (Kompas, 2009). Tidak ada bantuan hukum ditawarkan oleh negara kepada nenek Minah dan negara juga tidak memberikan informasi mengenai peraturan hukum yang dikenakan kepadanya sebelumnya.

\section{Permasalahan Mitra}

Dari pemaparan pada analisis situasi di atas maka yang menjadi permasalahan mitra di dalam Pengabdian Kepada Masyarakat ini adalah: Pertama, minimnya pengetahuan mitra tentang Bantuan Hukum, Kedua, Mitra kurang paham tentang Tata Cara Mendapatkan Bantuan Hukum.

\section{METODE}

Permasalahan yang dihadapi mitra adalah, Pertama, minimnya pengetahuan mitra tentang Bantuan Hukum, Kedua, Mitra kurang paham tentang Tata Cara Mendapatkan Bantuan Hukum. Dengan adanya kegiatan ini Masyarakat akan dapat meningkatkan pemahaman terhadap proses untuk mendapatkan hak setiap orang dalam meghadapi masalah hukum.

Metode pendekatan pelaksanaan kegiatan pengabdian kepada masyarakat ini adalah dengan menggunakan metode ceramah, dialog, dan diskusi dengan jumlah masyarakat 30 (tiga puluh) orang, dalam rangka penyuluhan hukum atau membedah isi Peraturan Perundang-undangan tentang Hak-hak Bantuan Hukum.

Partisipasi mitra dalam penyelenggaraan kegiatan ini adalah menyediakan tempat pelaksanaan, mengundang masyarakat yang membutuhkan pemahaman dan memfasilitasi semua pelaksanaan kegiatan ini.

Evaluasi dilakukan dengan membagikan kuesioner sebelum dan sesudah kegiatan dilaksanakan untuk mengukur tingkat pemahaman masyarakat terhadap proses untuk mendapatkan bantuan hukum. Untuk evaluasi keberhasilan pelaksanaan kegiatan pegabdian pada masyarakat ini adalah diukur dari antusias peserta yang mengikuti kegiatan ini dan banyaknya pertanyaanpertanyaan yang diajukan oleh para peserta.

\section{HASIL DAN PEMBAHASAN}

Kegiatan Pengabdian kepada masyarakat ini telah dilaksanakan pada hari Senin tanggal 22 Februari 2018 bertempat di Rumah Pak Yanto Salah seorang Rumah Penduduk di Desa batang Kulim Kabupaten Pelalawan Riau pada saat wirid Mingguan masyarakat, hadir disana Ketua RT, Ketua BPD dan Perangkat Desa Batang Kulim. Kegiatan ini dimulai Pukul 20.00 WIB sampai dengan 22.00 WIB. Jumlah peserta yang hadir adalah sebanyak 30 orang.

Dalam pelaksanaan kegiatan ini para peserta sangat antusias dalam mengikuti rangkaian acara hingga selesai, hal ini dapat dilihat saat sesi dialog tanya jawab antara peserta dengan nara sumber. Dari pertanyaan-pertanyaan yang dilontarkan oleh peserta dapat diambil kesimpulan bahwa adanya hasil transfer ilmu pegetahuan kepada khalayak sasaran sesuai dengan yang direncanakan oleh tim pengadian kepada masyarakat. Antusias peserta dalam mengikuti kegiatan ini juga dapat dilihat dari adanya Konsumsi yang disediakan oleh peserta kepada tim pengabdian masyarakat.

Evaluasi pegabdian kepada masyarakat ini dilakukan dengan cara membagikan kuisioner berupa pertanyaan yang harus dijawab oleh peserta yang berjumlah 30 orang. Pertanyaan yang 
dibuat dalam kuisioner adalah tentang pemahaman masyarakat terhadap proses untuk mendapatkan bantuan hukum secara Cuma-Cuma Tentang Bantuan Hukum. Sebaran kuisioner ini bertujuan untuk mengukur tingkat pengetahuan dan pemahaman masyarakat terhadap proses mendapatkan Bantuan Hukum. Untuk mengetahui tingkat pengetahuan dan pemahaman Masyarakat terhadap bantuan hukum Cuma-cuma. dapat dilihat dari data data di bawah ini:

\section{Pertanyaan :}

1. Apakah saudara mengetahui Undang-undang Nomor 16 tahun 2011 tentang Bantuan Hukum?

Berdasarkan hasil jawaban dari peserta melalui kuisioner yang dibagikan sebelum kegiatan dilaksanakan dan setelah kegiatan pengabdian kepada masyarakat ini dilaksanakan. Sebelum kegiatan dilaksanakan peserta yang mengetahui Undang-undang Nomor 16 tahun 2011 tentang Bantuan Hukum, dari 30 orang peserta yang menjawab A (YA), sebanyak 8 orang (26,67 \%), dan peserta yang menjawab B (TIDAK), sebanyak 22 orang $(73,33 \%)$.

Jawaban peserta setelah kegiatan pengabdian kepada masyarakat ini dilaksanakan yang menjawab A (YA), bertambah menjadi 23 orang $(76,67 \%)$ dan peserta yang menjawab B (TIDAK), berkurang menjadi hanya 7 orang $(23,33 \%)$.

Berdasarkan dari hasil jawaban kuisioner tersebut dapat diketahui bahwa pemahaman Masyarakat terhadap Undang-undang Nomor 16 tahun 2011 tentang Bantuan Hukum sebelum kegiatan ini dilaksanakan masih rendah (banyak yang kurang paham). Akan tetapi setelah kegiatan dilaksanakan ada peningkatan pemahaman peserta terhadap Undang-undang Nomor 16 tahun 2011 tentang Bantuan Hukum, hingga 50\%. Hal ini merupakan prestasi yang sangat membanggakan bagi tim pelaksana pengabdian kepada masyarakat.

\section{Pertanyaan :}

1. Apakah saudara mengetahui tentang ketentuan apa saja yang di atur dalam Undang-undang Nomor 16 tahun 2011 tentang Bantuan Hukum?

Berdasarkan hasil jawaban dari peserta melalui kuisioner yang dibagikan sebelum kegiatan dan sesudah kegiatan pengabdian kepada masyarakat ini dilaksanakan. Sebelum kegiatan dilaksanakan peserta yang mengetahui ketentuan apa saja yang di atur dalam Undang-undang Nomor 16 tahun 2011 tentang Bantuan Hukum, dari 30 orang peserta yang menjawab A (YA), sebanyak 3 orang (10,00 \%), dan peserta yang menjawab B (TIDAK), sebanyak 27 orang $(90,00$ $\%)$.

Jawaban peserta sesudah kegiatan pengabdian kepada masyarakat ini dilaksanakan yang menjawab A (YA), bertambah menjadi 20 orang $(66,66 \%)$ dan peserta yang menjawab B (TIDAK), berkurang menjadi 10 orang $(33,33 \%)$.

Berdasarkan dari hasil jawaban kuisioner tersebut dapat diketahui bahwa pemahaman peserta tentang ketentuan apa saja yang di atur ketentuan apa saja yang di atur dalam Undangundang Nomor 16 tahun 2011 tentang Bantuan Hukum sebelum pengabdian kepada masyarakat ini dilaksanakan masih banyak yang kurang paham. Akan tetapi sesudah kegiatan dilaksanakan ada peningkatan pemahaman peserta tentang syarat dan tata cara pemberian bantuan hukum untuk masyarakat miskin, ada peneningkatan yang sangat signifikan, mencapai sampai dengan 60,00\%.

\section{Pertanyaan :}

2. Apakah saudara mengetahui bahwa adanya layanan Pos Bantuan Hukum di Pengadilan bagi masyarakat miskin?

Hasil Kuisioner dapat diketahui bahwa peserta yang memahami bahwa adanya layanan Pos Bantuan Hukum di Pengadilan bagi masyarakat miskin, sebelum kegiatan dilaksanakan yang memilih jawaban A (YA) sebanyak 5 orang $(16,66 \%)$, sedangkan peserta yang memilih jawaban B (TIDAK), sebanyak 25 orang $(83,33 \%)$. Berdasarkan hasil jawaban tersebut menunjukkan bahwa peserta masih banyak yang belum mengetahui bahwa adanya layanan Pos Bantuan Hukum di Pengadilan bagi masyarakat miskin. Sedangkan jawaban setelah kegiatan dilaksanakan yang menjawab A (YA) sebanyak 28 orang $(93,33 \%)$ ada peningkatan pemahaman mahasiswa yang sangat signifikan yaitu meningkat sebesar $76,67 \%$ (persen). Sedangkan yang menjawab B (TIDAK) sebanyak 2 orang (6,67 \%), ada penurunan yang signifikan sebesar 76,66\% (persen). 
Pengukuran ini diambil berdasarkan hasil kuisioner yang dibagikan sebelum kegiatan dilaksanakan dan kuisioner yang dibagikan setelah kegiatan dilaksanakan. Dapat disimpulkan bahwa pengabdian kepada masyarakat ini sangat bermanfaat bagi masyarakat Desa Batang Kulim Kabupaten Pelalawan Provinsi Riau.

\section{Pertanyaan :}

3. Apakah saudara mengetahui proses untuk mendapatkan layanan Pos Bantuan Hukum di Pengadilan bagi masyarakat miskin?

Berdasarkan hasil jawaban dari peserta melalui kuisioner yang dibagikan sebelum kegiatan dan sesudah kegiatan pengabdian kepada masyarakat ini dilaksanakan. Sebelum kegiatan dilaksanakan peserta yang mengetahui proses mendapatkan layanan Pos Bantuan Hukum di Pengadilan bagi masyarakat miskin, dari 30 orang peserta yang menjawab A (YA), sebanyak 10 orang (33,33\%), dan peserta yang menjawab B (TIDAK), sebanyak 20 orang $(66,67 \%)$.

Jawaban peserta setelah kegiatan pengabdian kepada masyarakat ini dilaksanakan yang menjawab A (YA), bertambah menjadi 23 orang $(76,67 \%)$ dan peserta yang menjawab B (TIDAK), berkurang menjadi 7 orang $(23,33 \%)$.

Berdasarkan hasil jawaban kuisioner tersebut dapat disimpulkan bahwa pemahaman peserta terhadap proses untuk mendapatkan bantuan hukum untuk masyarakat miskin sebelum pengabdian kepada masyarakat ini dilaksanakan masih banyak yang kurang paham. Akan tetapi sesudah kegiatan dilaksanakan ada peningkatan pemahaman peserta terhadap proses untuk mendapatkan bantuan hukum secara cuma cuma ada peningkatan sampai dengan 43,34\%.

\section{Pertanyaan :}

4. Apakah kegiatan penyuluhan hukum ini memberikan manfaat bagi saudara?

Berdasarkan hasil jawaban dari peserta melalui kuisioner yang dibagikan sebelum kegiatan dan sesudah kegiatan pengabdian kepada masyarakat ini dilaksanakan. Sebelum kegiatan dilaksanakan dari 40 orang peserta, yang menjawab A (YA), sebanyak 28 orang 93,33\%), dan peserta yang menjawab B (TIDAK), sebanyak 2 orang $(6,67 \%)$.

Jawaban peserta sesudah kegiatan pengabdian kepada masyarakat ini dilaksanakan yang menjawab A (YA), adalah 30 orang (100\%) dan peserta yang menjawab B (TIDAK), menjadi tidak ada atau $(0 \%)$.

Berdasarkan dari hasil jawaban kuisioner dari peserta tersebut dapat disimpulkan bahwa pengabdian kepada masyarakat ini wajib dilakukan secara berkesinambungan terutama bagi masyarakat khususnya masyarakat Desa Batang Kulim Kabupaten Pelalawan Riau.

Berdasarkan dari hasil evaluasi melalui sebaran kuisioner dan jawaban peserta tersebut terlihat bahwa secara keseluruhan pengabdian kepada masyarakat ini perlu di tindak lanjuti baik melalui penyuluhan hukum, sosialisasi undang-undang maupun melalui pelatihan dan seminar untuk mewujudkan pembangunan sumber daya manusia yang selalu pro aktif dalam pembangunan nasional.

\section{Luaran yang dicapai}

Berdasarkan evaluasi melalui sebaran kuisioner dan jawaban peserta setelah kegitan pengabdian kepada masyarakat ini dilaksanakan terlihat bahwa secara keseluruhan pengabdian kepada masyarakat ini dengan judul " Peningkatan Pemahaman Masyarakat Desa Batang Kulim Kabupaten Pelalawan Provinsi Riau mengenai Undang-undang Nomor 16 Tahun 2011 tentang Bantuan Hukum", sangat membanggakan Tim sehubungan dengan adanya hasil yang diharapkan yaitu peningkatan pemahaman dan pengetahuan bagi mitra. Hal ini dapat dibuktikan banyaknya pertanyaan yang dilontarkan para peserta, antara lain, Bapak Yanto, mempertanyakan, tentang persyaratan yang harus dibawa ketika Surat keterangan Tidak Mampu tidak ada. Pertanyaan ini diberi jawaban oleh narasumber Untuk Masyarakat Miskin penerima bantuan hukum boleh menggantinya dengan Kartu Bantuan lansung Tunai (BLT), Surat Pernyataan tidak mampu membayar jasa advokat, Surat Keterangan tidak mampu dari kepala kepolisian, rutan, kejati, kapengadilan. Jadi, pemerintah dalam hal ini tidak mempersulit akses untuk mendapatkan bantuan hukum bagi masyarakat miskin. Selanjutnya salah seorang peserta yang berasal dari pegawai Desa 
Batang Kulim yaitu Bapak Lenes, mempertanyakan tentang Kasus apa saja yang bisa mendapatkan bantuan hukum secara Cuma-Cuma dari organisasi bantuan hukum. Narasumber menceritakan, semua jenis perkara baik litigasi maupun non litigasi contoh dari non litigasi adalah konsultasi hukum, drafting hukum, penyuluhan hukum, mediasi itu semua bisa dibantu oleh lembaga bantuan hukum. Dan Ruslam, mempertanyakan tentang Siapa saja yang menjadi anggota dari organisasi bantuan hukum $(\mathrm{OBH})$. Narasumber berbicara sesuai undang nomor 16 tahun 2011 anggota dari OBH adalah terdiri dari advokat, paralegal, dosen, mahasiswa fakultas hukum yang sudah lulus hukum acara. Anggota tersebut boleh melaksanakan bantuan hukum untuk masyarakat miskin dan tidak boleh meminta bayaran sedikitpun ke penerima bantuan hukum.

Pengabdian kepada masyarakat yang dilaksanakan oleh Tim dari Fakultas Hukum Univetrsitas Lancang Kuning, dapat mengembangkan dan mensukseskan pembangunan Sumber daya manusia, serta meningkatkan kemampuan ilmu pengetahuan dan pemahaman bagi Masyarakat Desa Batang Kulim Kecamatan Pangkalan Kuras Kabupaten Pelalawan Provinsi Riau dalam memecahkan masalahnya sendiri. Karena itu pengabdian kepada masyarakat ini harus diarahkan pada aktifitas yang manfaatnya dapat langsung di rasakan oleh mitra itu sendiri. Secara Khusus:

a. Mempercepat upaya peningkatan pemahaman dan pengetahuan dikalangan masyarakat khususnya pada Masyarakat Desa Batang Kulim Kecamatan Pangkalan Kuras Kabupaten Pelalawan Provinsi Riau;

b. Mempercepat upaya peningkatan kemampuan sumber daya manusia dengan tuntutan dinamika pembangunan melalui penyuluhan dan pelatihan;

c. mempercepat upaya pengembangan masyarakat kearah terbinanya masyarakat dinamis yang siap menempuh perubahan menuju perbaikan dan kemajuan yang sesuai dengan nilai-nilai sosial, lebih-lebih diera keterbukaan/transparansi sekarang ini;

d. Memperkenalkan Fakultas Hukum Unilak kepada masyarakat dan sekaligus sebagai "Arena Promosi" bagi Fakultas Hukum Unilak sendiri.

\section{KESIMPULAN}

Dari pelaksanaan kegiatan ini dapat diambil kesimpulan yaitu, terdapat Peningkatan pemahaman masyarakat Desa Batang Kulim Kabupaten Pelalawan Provinsi Riau mengenai Undang-undang Nomor 16 tahun 2011 tentang Bantuan Hukum. Hal ini dapat dilihat dari jawaban dalam kuisioner peserta sebelum kagiatan dilaksanakan. Setelah kegiatan dilaksanakan terdapat peningkatan yang sangat seignifikan dalam jawaban kusioner peserta meningkat.

Pemahaman masyarakat Desa Batang Kulim Kabupaten Pelalawan Provinsi Riau tentang hak setiap orang untuk mendapatkan bantuan hukum bagi masyarakat miskin masih Kurang. Hal ini dapat dilihat dari jawaban dalam kuisioner peserta sebelum kagiatan dilaksanakan. Setelah kegiatan dilaksanakan terdapat peningkatan yang sangat seignifikan dalam jawaban kusioner peserta meningkat.

\section{SARAN}

Dari kesimpulan yang telah disebutkan di atas, maka timbul harapan dari tim, untuk mewujudkan harapan tersebut maka tim memberikan saran-saran sebagai berikut:

1. Pengabdian kepada masyarakat harus di arahkan kepada Penyuluhan Hukun baik berupa Pelatihan, Seminar, dan Sosialisasi peraturan perundang-undangan, terutama undang-undang yang baru disahkan.

2. Pemerintah Perlu mensosialisasikan tentang mengenai Undang-undang Nomor 16 tahun 2011 tentang Bantuan Hukum pada seluruh daerah di Provinsi Riau karena banyak masyarakat yang membutuhkan informasi itu. 
DINAMISIA - Jurnal Pengabdian Kepada Masyarakat Vol. 2, No. 2 Desember 2018, Hal. 240-246

\section{DAFTAR PUSTAKA}

[1] Adnan Buyung Nasution, Pengantar Bantuan Hukum, 2010, Lembaga Bantuan Hukum, Jakarta.

[2] Asfinawati, Prolog: Bantuan Hukum Cuma-Cuma dan Komersialisasi,2007, dalam Lembaga Bantuan Hukum Jakarta, Bantuan Hukum Akses Masyarakat Miskin dan Marjinal terhadap Keadilan, LBH Jakarta, Jakarta.

[3] Pujiono, Bantuan Hukum dalam Perspektif Tanggungjawab Negara, Makalah disampaikan dalam Kegiatan Seminar "Bantuan Hukum dan Akses terhadap Keadilan Bagi Masyarakat Marginal”, Semarang, 09 Pebruari 2010.

[4] Undang Undang Dasar Negara Republik Indonesia tahun 1945.

[5] Undang undang Nomor 12 tahun 2011 tentang Pembetukan peraturan Perundang-undangan.

[6] Undang Undang Nomor 16 tahun 2011 tentang Bantuan Hukum.

[7] Peraturan Pemerintah Nomor 42 tahun 2013 tentang Syarat dan Tata Cara Pemberian Bantuan Hukum.

[8] Perma Nomor 1 Tahun 2014 tentang Pedoman Pemberian Layanan Hukum Bagi Masyarakat Tidak Mampu di Pengadilan. 